ISSN 0258-7122

Bangladesh J. Agril. Res. 40(4): 683-692, December 2015

\title{
GENETIC DIVERGENCE IN PUMPKIN (Cucurbita moschata L.) GENOTYPES
}

\author{
S. SULTANA ${ }^{1}$, M. A. KAWOCHAR ${ }^{2}$, S. NAZNIN ${ }^{3}$ \\ H. RAIHAN ${ }^{4}$ AND F. MAHMUD 5
}

\begin{abstract}
Genetic diversity using Mahalanobis's $\mathrm{D}^{2}$ technique was studied for yield and its components on twenty one genotypes of pumpkin (Cucurbita moschata L.). Quantification of variability for each character was done using the Shannon Weaver Diversity Index. High degree of variation was exhibited within the collection, as reflected by mean diversity index value of 0.80 . Data were subjected to principal component analysis (PCA), principal coordinate analysis (PCO), canonical variate analysis (CVA) and non-hierarchical clustering to identify suitable parents having distant relationship for hybridization program. The genotypes were grouped into five different clusters. Cluster IV contained the maximum number of seven genotypes whereas cluster I contained least number having only one genotype. The lowest inter-genotypic distance $(0.75)$ was found between BD-2174 and BD-9489 where the highest (47.46) was between BARI Mistikumra-1 and BD-2150. The maximum inter cluster distance was observed between cluster II and III (17.922) and the minimum inter cluster distance was observed between cluster II and IV (6.825). The maximum intra cluster distance was noticed for the cluster V (0.261) and the minimum intra cluster distance was found in cluster I (0.00). Cluster I contained the highest mean values for pedicel length of male flower, number of male flowers/plant, fruit length, fruit breadth, single fruit weight and fruits/plant. Cluster II contained the highest mean values for days to first male and female flowering. Cluster III contained the highest mean values for leaf breadth, pedicel length of female flower and number of female flowers/plant. Leaf breadth, pedicel length of male flower, number of male flowers/plant and fruits/plant were the important components of genetic divergence in the studied materials. Based on inter cluster distance, inter genotypic distance and consideration of desirable characters for high yield potential, the genotypes G19 (BARI mistikumra-1) and G20 (BARI mistikumra-2) from cluster II; G21 (BD-2150) from cluster I and G1 (BD-2151) and G13 (BD-266) from cluster III can be selected as better parents for future hybridization program.
\end{abstract}

Keywords: Cucurbita moschata L., principal component analysis, cluster analysis, genetic divergence.

\footnotetext{
${ }^{1-3}$ Scientific Officer (Plant Breeding), Tuber Crops Research Centre, Bangladesh Agricultural Research Institute (BARI), Gazipur-1701, ${ }^{4}$ Scientific Officer, Agricultural Research Station, BARI, Gazipur-1701, ${ }^{5}$ Professor, Department of Genetics and Plant Breeding, Sher-e-Bangla Agricultural University, Dhaka-1207, Bangladesh.
} 


\section{Introduction}

Pumpkin (Cucurbita moschata L.) is locally known as 'Misti kumra' or 'Misti lau' or 'Misti kadu' and is considered to have originated from Central and North America (Whitaker and Davis, 1962). It is an under exploited popular vegetable but has higher demand in Bangladesh. It is relatively high in energy and carbohydrates and a good source of vitamins, especially high carotenoid pigments and minerals (Bose and Som, 1986). It may contribute to improve the nutritional status of the people, particularly the vulnerable groups in respect of vitamin A requirement. It becomes available even in the lean period when other vegetables are scarce in Bangladesh. Among the non-traditional crops, Bangladesh has been earning a handsome amount of foreign currency by exporting pumpkin to the U.K., Pakistan and Middle East (Alamgir, 1998). The total production of pumpkin is 0.218 million tons in a year in this country (BBS, 2011). Lack of high yielding, disease and pest tolerant variety is the main constrains towards its production. For developing a high yielding variety with desired characters needs good parents. The selection of potential good parents in a breeding program is based on the knowledge of genetic diversity amongst them. Evaluation of genetic diversity is important to know the source of genes for a particular character within the available germplasm (Tomooka 1991). To realize heterosis, genetically divergent parents are generally considered to be useful. In such crosses more variability could be expected in the resulting segregating progenies. Genetic divergence can be estimated by $\mathrm{D}^{2}$ Statistic suggested by Mahalanobis and in turn is based on multivariate analysis of quantitative characters. The present study has been undertaken to generate information on genetic divergence in pumpkin so that the useful parental material for the breeding programs could be selected.

\section{Materials and Method}

The investigation was carried out at the experimental field of Sher-e-Bangla Agricultural University, Bangladesh during the period from March 2010 to August 2010 to study the genetic diversity in pumpkin. Twenty one genotypes of pumpkin were used in Randomized Complete Block Design (RCBD) with three replications. Those genotypes were assigned at random into pits of each replication. Pits of $55 \mathrm{~cm} \times 55 \mathrm{~cm} \times 50 \mathrm{~cm}$ were prepared in each plot with spacing of $3 \mathrm{~m} \times 3 \mathrm{~m}$. Number of pits/plot were 3. Standard package of cultural practices was followed for raising healthy crops. For studying different genetic parameters and inter-relationships, thirteen characters were taken into consideration like leaf length $(\mathrm{cm})$, leaf breadth $(\mathrm{cm})$, internodes distance $(\mathrm{cm})$, days to first male flowering, days to first female flowering, pedicel length of male flower $(\mathrm{cm})$, pedicel length of female flower $(\mathrm{cm})$, number of male flowers, number of female flowers, fruit length $(\mathrm{cm})$, fruit breadth $(\mathrm{cm})$, fruit weight $(\mathrm{Kg})$ and fruit yield/ plant $(\mathrm{Kg})$. 
Quantification of variability for each character was done using the ShannonWeaver Diversity Index. Estimate of variability for each character was computed using the standardized Shannon-Weaver Diversity Index, designated as H' and has the formula:

$$
\mathrm{H}^{\prime}=-\sum \mathrm{Pi}\left(\log _{2} \mathrm{Pi}\right) / \log _{2} \mathrm{n}
$$

Where, $\mathrm{Pi}$ is the proportion of the total number of genotypes belonging to the $\mathrm{i}^{\text {th }}$ class.

For each quantitative characters, the overall genotype means $(\mathrm{x})$ and standard deviation $(\sigma)$ were used to subdivide the population values $\left(\mathrm{x}_{\mathrm{i}}\right)$ into 10 frequency classes, ranging from class 1 (if $\left.x_{i} \leq-2 \sigma\right\}$ to class 10 (if $x i \leq X+2 \sigma$ ), the class interval being $0.5 \sigma$. The lowest and highest values were considered to determine the number of classes construct. The diversity considered high when $\mathrm{H}^{\prime}>0.75$, moderate when $\mathrm{H}^{\prime}=0.50-0.75$ and low when $\mathrm{H}^{\prime}<0.50$. The Shannon-Weaver Diversity Index has a value ranging from 0 to 1 , where 0 indicates absence of diversity and 1 indicates maximum diversity.

For both univariate and multivariate analysis, mean data for each character was used. In case of univariate analysis, analysis of variance was done individually by F test (Panse and shuhkhatme, 1978) and MSTATC software was used for this purposes. Multivariate analysis viz. Principal Component Analysis (PCA), Principal Coordinate Analysis (PCO), Cluster Analysis, and Canonical Vector Analysis (CVA) were done by using Genestat 5.13 software program.

\section{Result and Discussion}

The analysis of variance showed significant variations among the genotypes for all the characters studied (Table 1).

\section{Estimation of variation Using the Shannon- Weaver Diversity Index}

Only two characters like days to first male flowering (0.73) and leaf breadth (0.74) exhibited medium variation while all the rest gave high diversity values. The computed diversity ranged from 0.73 (days to first male flowering) to 0.85 (leaf length) with a mean diversity value of 0.80 indicated existence of high variation within the collection (Table 2).

\section{Cluster analysis}

Based on cluster analysis, the twenty one genotypes were grouped into five clusters (Table 3). Cluster IV contained the maximum number of seven genotypes followed by cluster III, V and II having six, five and two, respectively, while cluster I contained least number of one genotype. In many cases, the same cluster included genotypes from different eco-geographic region indicating that 
the geographic distribution and genetic divergence did not follow the same trend. The mean performances of thirteen characters in five clusters are shown in Table 4. Most of the characters showed distinct differences among the clusters. Cluster I contained the highest mean values for pedicel length of male flower (22.60), number of male flowers/plant (9.33), fruit length (74.40), fruit breadth (35.00), single fruit weight (3.58) and fruits/plant (7.15), whereas the lowest mean values for internodes distance (11.33). Cluster II contained the highest mean values for days to first male flowering (85.83), days to first female flowering (86.83) and the lowest mean values for leaf length (12.83), leaf breadth (18.33), pedicel length of male flower (8.23), pedicel length of female flower (2.09), number of male flowers/plant (1.00), number of female flowers/plant (1.00), fruit length (40.06), fruit breadth (18.03), single fruit weight (0.85) and fruits/plant (0.85). Cluster III got the highest mean values for pedicel length of female flower (5.52) and number of female flowers/ plant (4.78) while the lowest values for days to first male flowering (63.06) and days to first female flowering (67.78). Cluster IV contained the highest mean values for leaf breadth (25.77) and internodes distance (15.19).

Table 1. Range, Mean, Mean sum of square (MSG), Percent coefficient of variation (CV) of 21 pumpkin genotypes.

\begin{tabular}{lcc|c|c}
\hline \multicolumn{1}{c}{ Parameters } & Range & Mean & MS $_{\mathrm{G}}$ & $\mathrm{CV}(\%)$ \\
\hline Leaf length without petiole (cm) & $11.33-21.60$ & 17.20 & $24.51^{* *}$ & 5.23 \\
Leaf breadth (cm) & $15.20-30.67$ & 23.39 & $38.32^{* *}$ & 4.70 \\
Internodes distance & $10.00-20.00$ & 14.17 & $29.12^{* *}$ & 14.73 \\
Days to first male flowering & $60.00-86.33$ & 70.38 & $150.44^{* *}$ & 6.07 \\
Days to first female flowering & $65.67-87.00$ & 75.17 & $135.82^{* *}$ & 5.31 \\
Pedicel length of male flower (cm) & $8.07-26.47$ & 16.67 & $105.05^{* *}$ & 6.73 \\
Pedicel length of female flower (cm) & $2.07-8.63$ & 4.45 & $9.94^{* *}$ & 8.35 \\
Number of male flowers/plant & $1.00-15.33$ & 6.77 & $40.94^{* *}$ & 34.57 \\
Number of female flowers/plant & $1.00-7.00$ & 3.53 & $11.34^{* * *}$ & 52.68 \\
Fruit length (cm) & $39.60-74.40$ & 53.34 & $201.36^{* *}$ & 9.87 \\
Fruit breadth (cm) & $17.33-35.00$ & 27.59 & $65.34^{* * *}$ & 10.04 \\
Single fruit weight (kg) & $0.80-3.58$ & 2.09 & $1.77^{* *}$ & 17.02 \\
Fruit yield/plant (kg) & $0.80-9.92$ & 4.01 & $21.00^{* *}$ & 40.09 \\
\hline
\end{tabular}

** Variation is significant at $1 \%$ level of probability. 
Table 2. Computed diversity indices (H') for 13 different characters of 21 pumpkin genotypes.

\begin{tabular}{lc}
\hline Characters & $\mathrm{H}^{\prime}$ \\
\hline Leaf length without petiole $(\mathrm{cm})$ & 0.85 \\
Leaf breadth $(\mathrm{cm})$ & 0.74 \\
Internodes distance & 0.81 \\
Days to first male flowering & 0.73 \\
Days to first female flowering & 0.82 \\
Pedicel length of male flower $(\mathrm{cm})$ & 0.81 \\
Pedicel length of female flower $(\mathrm{cm})$ & 0.83 \\
Number of male flowers/plant & 0.78 \\
Number of female flowers/plant & 0.81 \\
Fruit length (cm) & 0.84 \\
Fruit breadth (cm) & 0.75 \\
Single fruit weight (kg) & 0.84 \\
Fruit yield/plant $(\mathrm{kg})$ & 0.82 \\
\hline Average & 0.80 \\
\hline
\end{tabular}

Table 3. Distribution of genotypes in different clusters.

\begin{tabular}{|c|c|c|c|}
\hline $\begin{array}{l}\text { Cluster } \\
\text { no. }\end{array}$ & No. of Genotypes & $\begin{array}{c}\text { No. of } \\
\text { population }\end{array}$ & Name of genotypes \\
\hline I & G21 & 1 & BD-2150 \\
\hline II & G19, G20 & 2 & $\begin{array}{l}\text { BARI mistikumra-1, BARI } \\
\text { mistikumra-2 }\end{array}$ \\
\hline III & G1, G2, G9, G10, G11, G13 & 6 & $\begin{array}{l}\text { BD-266, BD-2214, BD-2151, } \\
\text { BD-2153, BD-2229, BD-2222 }\end{array}$ \\
\hline IV & $\begin{array}{l}\text { G3, G4, G6, G14, G15, G16, } \\
\text { G18 }\end{array}$ & 7 & $\begin{array}{l}\text { BD-2174, BD-2177, BD-2196, } \\
\text { BD-9489, BD-9494, BD-9491, } \\
\text { BD-9490 }\end{array}$ \\
\hline $\mathrm{V}$ & G5, G7, G8, G12, G17 & 5 & $\begin{array}{l}\text { BD-264, BD-2203, BD-2212, } \\
\text { BD-9493, BD-4590 }\end{array}$ \\
\hline
\end{tabular}

\section{Principal Coordinate Analysis (PCO)}

Inter-genotypic distances $\left(\mathrm{D}^{2}\right)$ were obtained from $\mathrm{PCO}$ for all possible combinations between pair of genotypes. Intergenotypic distances among the pumpkin genotypes ranged from 0.75 (between BD-2174 and BD-9489) to 47.46 (between BARI mistikumra-2 and BD-2150) (Table 5). The difference between the highest and lowest inter genotypic distance indicated the presence of variability among the twenty one pumpkin genotypes. 
Table 4. Cluster mean values of 13 different characters of 21 pumpkin genotypes.

\begin{tabular}{lcccccc}
\hline \multicolumn{1}{c|}{ Characters } & I & II & III & IV & V \\
\hline Leaf length without petiole (cm) & 17.67 & 12.83 & 18.40 & 17.83 & 16.53 \\
Leaf breadth (cm) & 21.87 & 18.33 & 23.47 & 25.77 & 22.29 \\
Internodes distance & 11.33 & 13.00 & 14.33 & 15.19 & 13.60 \\
Days to first male flowering & 70.67 & 85.83 & 63.06 & 69.91 & 73.60 \\
Days to first female flowering & 74.33 & 86.83 & 67.78 & 76.19 & 78.13 \\
Pedicel length of male flower (cm) & 22.60 & 8.23 & 20.86 & 12.47 & 19.71 \\
Pedicel length of female flower (cm) & 5.10 & 2.09 & 5.52 & 4.65 & 3.72 \\
Number of male flowers/plant & 9.33 & 1.00 & 7.72 & 7.05 & 7.07 \\
Number of female flowers/plant & 4.67 & 1.00 & 4.78 & 3.67 & 2.67 \\
Fruit length (cm) & 74.40 & 40.06 & 54.18 & 57.27 & 47.95 \\
Fruit breadth (cm) & 35.00 & 18.03 & 27.65 & 30.11 & 26.35 \\
Single fruit weight (kg) & 3.58 & 0.85 & 2.05 & 2.54 & 1.71 \\
Fruit yield/plant (kg) & 7.15 & 0.85 & 6.10 & 3.63 & 2.70 \\
\hline
\end{tabular}

Table 5.Ten of each higher and lower inter- genotypic distance $\left(D^{2}\right)$ among the 21 pumpkin genotypes.

\begin{tabular}{|c|c|c|c|c|c|c|c|}
\hline \multirow{2}{*}{$\begin{array}{r}\text { S1 } \\
\text { No. } \\
01\end{array}$} & \multicolumn{2}{|c|}{ Genotypic Combination } & \multirow{2}{*}{$\begin{array}{c}\text { Ten } \\
\text { Maximum } \\
\left(\mathrm{D}^{2)} \text { Values }\right. \\
47.46\end{array}$} & \multirow{2}{*}{\begin{tabular}{|r|} 
S1 \\
No. \\
01
\end{tabular}} & \multicolumn{2}{|c|}{ Genotypic Combination } & \multirow{2}{*}{\begin{tabular}{|c} 
Ten \\
Minimum \\
$\left(\mathrm{D}^{2)}\right.$ \\
Values \\
0.75
\end{tabular}} \\
\hline & $\begin{array}{l}\text { BD- } \\
2150-\end{array}$ & $\begin{array}{l}\text { BARI } \\
\text { mistikumra-2 }\end{array}$ & & & BD-2174 & - BD-9489 & \\
\hline 02 & $\begin{array}{l}\text { BD-2151 } \\
-\end{array}$ & $\begin{array}{l}\text { BARI } \\
\text { mistikumra-2 }\end{array}$ & 46.39 & 02 & BD-2177 & - BD-2214 & 1.42 \\
\hline 03 & $\begin{array}{l}\text { BD- } \\
2150-\end{array}$ & $\begin{array}{l}\text { BARI } \\
\text { mistikumra-1 }\end{array}$ & 46.04 & 03 & $\begin{array}{l}\text { BARI } \\
\text { mistikumra-1 }\end{array}$ & $\begin{array}{l}\text { - BARI } \\
\text { mistikumra-2 }\end{array}$ & 1.57 \\
\hline 04 & $\begin{array}{l}\text { BD-2151 } \\
-\end{array}$ & $\begin{array}{l}\text { BARI } \\
\text { mistikumra-1 }\end{array}$ & 44.82 & 04 & BD-9489 & - BD-9490 & 2.13 \\
\hline 05 & BD-266 - & $\begin{array}{l}\text { BARI } \\
\text { mistikumra-2 }\end{array}$ & 43.86 & 05 & BD-2174 & - BD-9490 & 2.41 \\
\hline 06 & $\begin{array}{l}\text { BD-2229 } \\
-\end{array}$ & $\begin{array}{l}\text { BARI } \\
\text { mistikumra-2 }\end{array}$ & 43.04 & 06 & BD-264 & - BD-9491 & 2.92 \\
\hline 07 & BD-266 - & $\begin{array}{l}\text { BARI } \\
\text { mistikumra-1 }\end{array}$ & 42.30 & 07 & BD-9490 & - BD-9491 & 3.45 \\
\hline 08 & $\begin{array}{l}\text { BD-2229 } \\
-\end{array}$ & $\begin{array}{l}\text { BARI } \\
\text { mistikumra-1 }\end{array}$ & 41.46 & 08 & BD-2196 & - BD-2214 & 3.60 \\
\hline 09 & $\begin{array}{l}\text { BD-2196 } \\
-\end{array}$ & $\begin{array}{l}\text { BARI } \\
\text { mistikumra-2 }\end{array}$ & 38.98 & 09 & BD-2151 & - BD-2229 & 3.71 \\
\hline 10 & $\begin{array}{l}\text { BD-2196 } \\
-\end{array}$ & $\begin{array}{l}\text { BARI } \\
\text { mistikumra-1 }\end{array}$ & 37.42 & 10 & BD-2174 & - BD-9491 & 3.74 \\
\hline
\end{tabular}

The intra-cluster distances were computed by using the values of inter-genotypic distances from distant matrix according to Sing and Chaudhury (1985). The 
magnitude of the intra cluster distances were not always proportional to the number of genotypes in the clusters (Huque et al, 2012), as the maximum intra cluster distance was noticed for the cluster V (0.261) followed by cluster III (0.177) and cluster IV (0.109). The minimum intra cluster distance was found in cluster I (0.00) followed by cluster II (0.01) (Table 6). This result supported by Gaffar (2008) and he reported that the genotypes were grouped into five clusters in which the highest intra cluster distance was noticed for the cluster II (0.999) and the lowest for the cluster IV (0.439).

Table 6. Intra (Bold) and inter cluster distances $\left(\mathrm{D}^{2}\right)$ for 21 pumpkin genotypes.

\begin{tabular}{c|c|c|c|c|c}
\hline Cluster & I & II & III & IV & V \\
\hline I & $\mathbf{0 0 . 0 0}$ & 15.472 & 11.858 & 6.825 & 10.326 \\
II & & $\mathbf{0 0 . 0 1}$ & 17.922 & 14.444 & 10.447 \\
III & & & $\mathbf{0 . 1 7 7}$ & 7.284 & 9.274 \\
IV & & & & $\mathbf{0 . 1 0 9}$ & 6.450 \\
V & & & & & $\mathbf{0 . 2 6 1}$ \\
\hline
\end{tabular}

Table 7. Eigenvalues and percentage of variation in respect of 13 principal components in 21 genotypes of pumpkin

\begin{tabular}{c|c|c|c}
\hline $\begin{array}{c}\text { Principal } \\
\text { component axis }\end{array}$ & Eigen values & Percent variation & $\begin{array}{c}\text { Cumulative \% of Percent } \\
\text { variation }\end{array}$ \\
\hline 1 & 5.735 & 44.12 & 44.12 \\
2 & 2.066 & 15.89 & 60.12 \\
3 & 1.684 & 12.95 & 72.96 \\
4 & 1.176 & 9.05 & 82.01 \\
5 & 0.812 & 6.24 & 88.25 \\
6 & 0.558 & 4.29 & 92.54 \\
7 & 0.328 & 2.53 & 95.07 \\
8 & 0.233 & 1.80 & 96.87 \\
9 & 0.185 & 1.42 & 98.29 \\
10 & 0.137 & 1.06 & 99.35 \\
11 & 0.035 & 0.27 & 99.62 \\
12 & 0.033 & 0.25 & 99.88 \\
13 & 0.018 & 0.13 & 100.00 \\
\hline
\end{tabular}

\section{Canonical Variate Analysis (CVA)}

The inter-cluster distances were obtained from CVA. The inter cluster distances were larger than intra cluster distances which indicated that wider genetic diversity among the genotypes of different groups. The maximum inter cluster distance was observed between cluster II and III (17.922) followed by cluster I and II (15.472), cluster II and IV (14.444). The maximum inter cluster distance indicated that the genotypes belonging to cluster II were far away from those of cluster III. The minimum inter cluster distance was observed between cluster IV 
and V (6.45) followed by I and IV (6.825) (Table 6). The results revealed that the crosses between the genotypes of cluster II and III would exhibit high heterosis and produce new recombinant with desirable traits.

\section{Principal Component Analysis (PCA)}

PCA is a statistical method which attempts to describe the total variation in multivariate sample using fewer variables than in the original data set (Bartolome et al., 1999). The analysis results in the identification of the major attributes that are responsible for the observed variation within a given collection. From principal component analysis the values were found as $72.96 \%$ in the first three components and it was $82.01 \%$ in the four components of the total variance (Table 7). The two dimensional scatter diagram was prepared by using score component 1 in $\mathrm{X}$ axis and 2 in $\mathrm{Y}$ axis, showing the groups into five clusters among the genotypes which supported the result of cluster analysis (Fig 1).

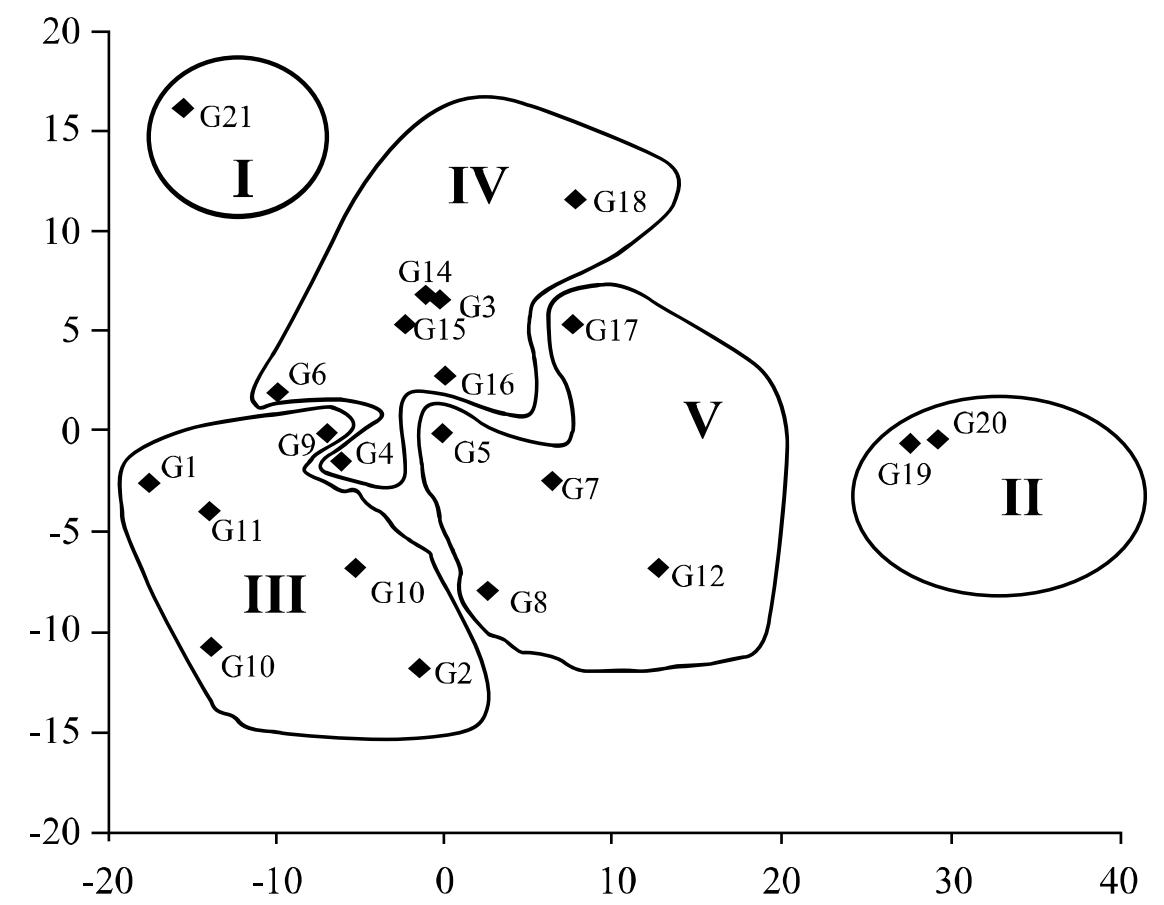

Fig. 1. Scattered diagram of 21 pumpkin genotypes of superimposed clusters

\section{Contribution of characters towards divergence of the genotypes}

Contribution of characters towards divergence of the genotypes is presented in table 8 . The result of principal component analysis revealed that in vector $I\left(Z_{1}\right)$, the important characters responsible for genetic divergence in the major axis of differentiation were leaf length, leaf breadth, days to first male flowering, pedicel 
length of male flower, number of male flowers/plant, number of female flowers/plant, single fruit weight and fruits/plant which accounted for $44.12 \%$ of the total variation. In vector II $\left(\mathrm{Z}_{2}\right)$, which was the second axis of differentiation, leaf breadth, internodes distance, days to first female flowering, pedicel length of male flower, pedicel length of female flower, number of male flowers/plant and fruits/plant were important. Those characters contribute $15.89 \%$ of the total variation. The role of leaf breadth, pedicel length of male flower, number of male flowers/plant and fruit yield/plant in both the vectors was positive, which indicate the important components of genetic divergence in the collected materials. Divergence in the collected materials due to these four characters will offer a good scope for improvement of yield through rational selection of parents for producing hybrids. Banik (2003) reported that main vine length, first female flower node number, nodes on main vine, fruit length and number of seeds/fruit in snake gourd had the highest contribution towards the divergence.

Table 8. Relative contributions of the thirteen characters of 21 pumpkin genotypes to the total divergence.

\begin{tabular}{l|c|c}
\hline \multicolumn{1}{c|}{ Characters } & Vector-1 & Vector-2 \\
\hline Leaf length without petiole $(\mathrm{cm})$ & 0.5349 & -0.1190 \\
Leaf breadth (cm) & 0.1333 & 0.0045 \\
Internodes distance & -0.1342 & 0.1140 \\
Days to first male flowering & 0.9228 & -0.3450 \\
Days to first female flowering & -0.0185 & 0.1123 \\
Pedicel length of male flower (cm) & 0.1329 & 0.0509 \\
Pedicel length of female flower (cm) & -0.5019 & 0.2415 \\
Number of male flowers/plant & 0.1079 & 0.2099 \\
Number of female flowers/plant & 0.3500 & -1.9159 \\
Fruit length (cm) & -0.0214 & -0.2980 \\
Fruit breadth (cm) & -0.4121 & -0.1813 \\
Single fruit weight $(\mathrm{kg})$ & 1.3447 & -1.4068 \\
Fruit yield/plant $(\mathrm{kg})$ & 0.0004 & 1.4252 \\
\hline
\end{tabular}

\section{Selection of genotypes}

It is generally assumed that maximum amount of heterosis would be manifested in cross combinations involving the genotypes belonging to the most divergent clusters. Genotypes in cluster II if crossed with cluster I and cluster III might exhibit high heterosis as well as wide spectrum of genetic variation in $F_{2}$ generation. Based on inter cluster distance, inter genotypic distance and consideration of desirable characters for high yield potential, the genotypes G19 
(BARI mistikumra-1) and G20 (BARI mistikumra-2) from cluster II; G21 (BD2150) from cluster I and G1 (BD-2151) and G13 (BD-266) from cluster III may be considered better parents for future hybridization program.

\section{References}

Alamgir, M. 1998. Export potential of non-traditional agricultural products (Bangladesh). Bangladesh Quarterly, 1(3): 12-13.

Bartolome, V. I., L. C. Quintana, A. B. Olea, L. C. Paunlagui, M. A. Ynalvez and C. G. Maclaren. 1999. Experimental design and data analysis for agricultural research.Volume 2. Training Documents. Biometrics Unit. International Rice Research Institute.

Banik, B. R. 2003. Variability, gene action and heterosis in snake gourd (Trichosanthes anguina L.). Ph.D. thesis, Department of Genetics and Plant Breeding. Bangabandhu Sheikh Mujibur Rahman Agricultural University, Salna, Gazipur, Pp. 1-60.

BBS (Bangladesh Bureau of Statistics). 2011. Statistical Year Book of Bangladesh 20102011. Bangladesh Bureau of Statistics Division, Ministry of Planning, Govt. of the People 's Republic of Bangladesh, Dhaka.

Bose,T. K. and M. G. Som. 1986. Vegetables Crops in India. Naya Prokash, Calcutta, India, Pp. 92-95.

Gaffar, A. 2008. Characterization and genetic diversity of sponge gourd (Luffa cylindrica L.). MS Thesis. Department of Genetics and Plant Breeding. Sher-eBangla Agricultural University, Dhaka.

Huque, A. K. M. H., M. K. Hossain, N. Alam, M. Hasanuzzaman and B. K. Biswas. 2012. Genetic divergence in yardlong bean (Vigna unguiculata (L.) walp. Ssp. Sesquipedalis verdc). Bangladesh J. Bot. 41(1):61-69.

Panse, V.G., and Sukhatme, P.V. 1978. Statistical methods for agricultural workers. I.C.A.R., New Delhi.

Singh, R.K. and B.D. Chaudhury. 1985. Biometrical methods in quantitative genetic analysis. Kalyani Publishers, New Delhi, India, P. 56.

Tomooka, N. 1991. Genetic diversity and landrace differentiation of mungbean, Vigna radiata (L) Wilczek, and evaluation of its wild relatives (The subgenus Ceratottropics) as breeding materials. Tech. Bull., Trop. Res. Center, Japan. No.28. Ministry of Agriculture, Forestry and Fisheries, Japan, Pp. 1.

Whitaker, T. W. and G. N. Davis.1962. Cucurbits. Interscience Pub. INC. New York, Pp. 13. 